Article

\title{
Case Study: Forecasting the Lower Vistula Bed Deformation without and with Development of Dam Cascade
}

\author{
Janusz Kubrak ${ }^{1, *(\mathbb{D}}$, Adam Kiczko ${ }^{1}$ and Elżbieta Kubrak $^{2} \mathbb{C}$ \\ 1 Institute of Environmental Engineering, Warsaw University of Life Sciences-WULS-SGGW, \\ 02-787 Warsaw, Poland; adam_kiczko@sggw.edu.pl \\ 2 Water Centre, Warsaw University of Life Sciences-WULS-SGGW, 02-787 Warsaw, Poland; \\ elzbieta_kubrak@sggw.edu.pl \\ * Correspondence: janusz_kubrak@sggw.edu.pl
}

check for updates

Citation: Kubrak, J.; Kiczko, A.; Kubrak, E. Case Study: Forecasting the Lower Vistula Bed Deformation without and with Development of Dam Cascade. Water 2021, 13, 2142. https://doi.org/10.3390/w13162142

Academic Editor: Bommanna Krishnappan

Received: 15 June 2021

Accepted: 27 July 2021

Published: 4 August 2021

Publisher's Note: MDPI stays neutral with regard to jurisdictional claims in published maps and institutional affiliations.

Copyright: (c) 2021 by the authors. Licensee MDPI, Basel, Switzerland. This article is an open access article distributed under the terms and conditions of the Creative Commons Attribution (CC BY) license (https:// creativecommons.org/licenses/by/ $4.0 /)$.

\begin{abstract}
The case study presents the results of numeric simulations of deformations of Vistula River bed downstream the Włocławek Dam, with and without development of the downstream dam cascade. Calculations were performed using a one-dimensional flow model MIKE11 with a river transport module. Using synthetic inflow hydrographs, predictions were performed for 39 year period (2016-2055). Results indicate that the construction of the dam cascade will reduce the erosion of the river bed downstream the Włocławek dam.
\end{abstract}

Keywords: dam cascade; river transport; dam effect on bed deformations

\section{Planned Vistula Dam Cascade}

Vistula is one of the largest European rivers. The $1047 \mathrm{~km}$ long Vistula is the longest river in Poland. Its $194,000 \mathrm{~km}^{2}$ catchment area is almost entirely within the borders of Poland. The average flow in the Vistula mouth to the Baltic Sea is $\sim 1046 \mathrm{~m}^{3} / \mathrm{s}$. The lower part of the Vistula River has a quite large hydro-energy potential. There have been many plans for the development of the Lower Vistula River so far [1].

In 1970, a water dam and a power plant were built in Włocławek $(674.850 \mathrm{~km}$ of the river-Figure 1, downstream-upstream stationing). It was assumed that it would be the first of many dams on the Vistula River. The next dams and hydropower plants in the lower reaches of the Vistula were to be built 10-15 years after the Włocławek dam was put into operation. The country's economic problems prevented the emergence of further dams. In order to optimally use the facility, the peak operation of the power plant was assumed, i.e., multiple water release a day. The assumed backwaters of the designed dam downstream Włocławek should enable complete shutdown of the facility for several hours, thus collecting water for hours of the peak demand. An exemplary hydrograph of hydropower work in this period is shown in Figure 2 [2].

It was assumed that prior to the construction of the subsequent dam in Ciechocinek, the determined minimum flow should be ensured $24 \mathrm{~h}$ a day, to maintain required water levels in the river channel downstream Wloclawek Dam. The peaks release from the reservoir were expected only when using excess water. Ultimately, the Ciechocinek Dam was not built, but the Włocławek power plant operated in this way for many years, which led to accelerated erosion of the riverbed downstream the dam. As a result, the downstream water levels got lowered. In 2002, the schema of the power plant's operation was changed. The damming of the Vistula with the Włocławek dam $(674.850 \mathrm{~km})$ caused increased erosion of the downstream Vistula channel $[3,4]$. The main cause was the slowing down of the water velocity upstream the dam, resulting in the deposition of sediment in the dam reservoir. The bathymetric measurements performed in the 1969-2008 period showed that during 39 years of operation of the Włocławek dam, the bottom of the downstream riverbed dropped by more than $3.5 \mathrm{~m}$. Comparing to the state before construction of the 
Włocławek dam, the bottom was lowered by 3.5-4.0 m immediately downstream the dam; 2.8-3.0 $\mathrm{m}$ in the line of the road bridge in Włocławek; $1.6 \mathrm{~m}$ on the section near Nieszawa $(703.750 \mathrm{~km})$; near Torun $(734.550 \mathrm{~km})$, about $0.5 \mathrm{~m}$ [5]. The development of the erosion downstream of the dam was characterized in terms of speed of the lowering of the channel bottom and the movement of the front of erosional zone shifting-boundary between the zone of intensive erosion and zone without it. The average annual speed of movement of the erosion front is determined as $1.9 \mathrm{~km} /$ year. It was estimated that 40 years after the construction of the dam in Włocławek, the front of the erosion zone would exceed the water gauge profile in Torun $(734.550 \mathrm{~km})$ and would be found probably in the area of Solec Kujawski $(758.000$ km), i.e., approximately $83 \mathrm{~km}$ from the dam in Włocławek [3-6].

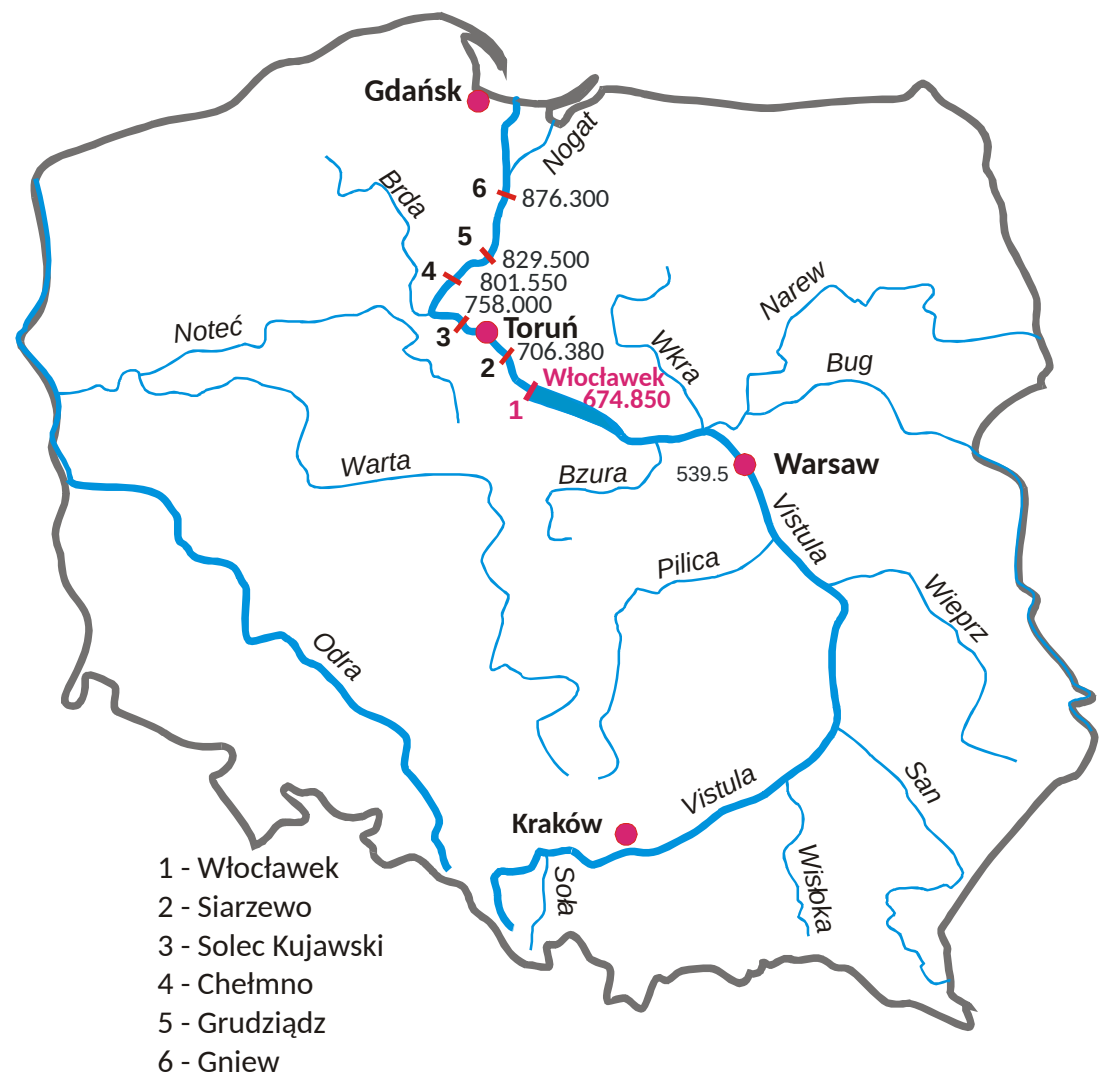

Figure 1. Location of the Włoclawek Dam and proposed further dam locations.

Currently, in a section almost $15 \mathrm{~km}$ downstream the Włocławek dam $(674.850 \mathrm{~km})$, the bottom of the Vistula riverbed is made of hardly erodible deposits, e.g., clay, often covered with moraine paving, and loams (without alluvia). The erosion process is limited here due to the elevation of the bottom material (sand-gravel) downstream and reaching erosion-resistant tertiary loam. From $707 \mathrm{~km}$ up to the town of Silno $(720 \mathrm{~km})$, the bottom substrate consists solely of sandy formations with a median grain diameter $\left(d_{50}\right)$ of 0.3 to $0.7 \mathrm{~mm}$. In this section, it is difficult to predict the bottom erosion boundary of the stream bed, because the hardly erodible materials are much deeper here. A sand material with such graining at the bottom of the Vistula River will not protect the bed against erosion, when the supply of sediment from the basin and lateral erosion of river banks would become limited. The analysis of the graining of the remains of alluvia in the longitudinal profile of the bed from the dam to Torun $(734.550 \mathrm{~km})$ shows that they are very diverse. They come from eroded side massifs and clumps and sandbanks, which were formed in the initial phase after the construction of the dam, and the majority of sand is medium and coarse-grained. The entrainment of sand and fine gravel alluvials in the river channel will continue until they are completely eroded. 


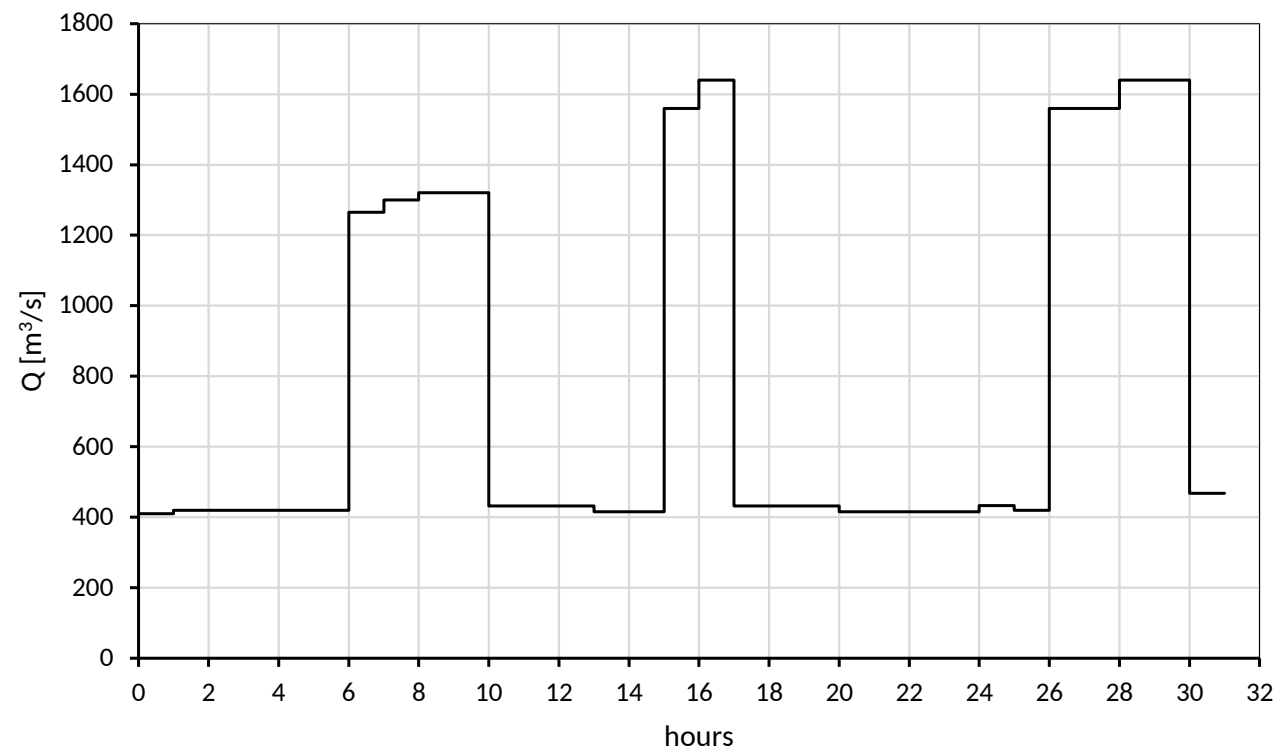

Figure 2. The example of the Wlocławek outflow hydrograph when it was operation in the peak system, 1 August 1987 time starts at 1.00 a.m.

Then, the bottom of the bed will be made of clay or moraine till [4,7].

In order to stop the triggered erosion processes, it is planned to build a cascade of five dams downstream the Włocławek dam over the period of 24 years (Figures 1 and 3).

The characteristics of the planned dams, downstream Włocławek are summarized in Table 1.

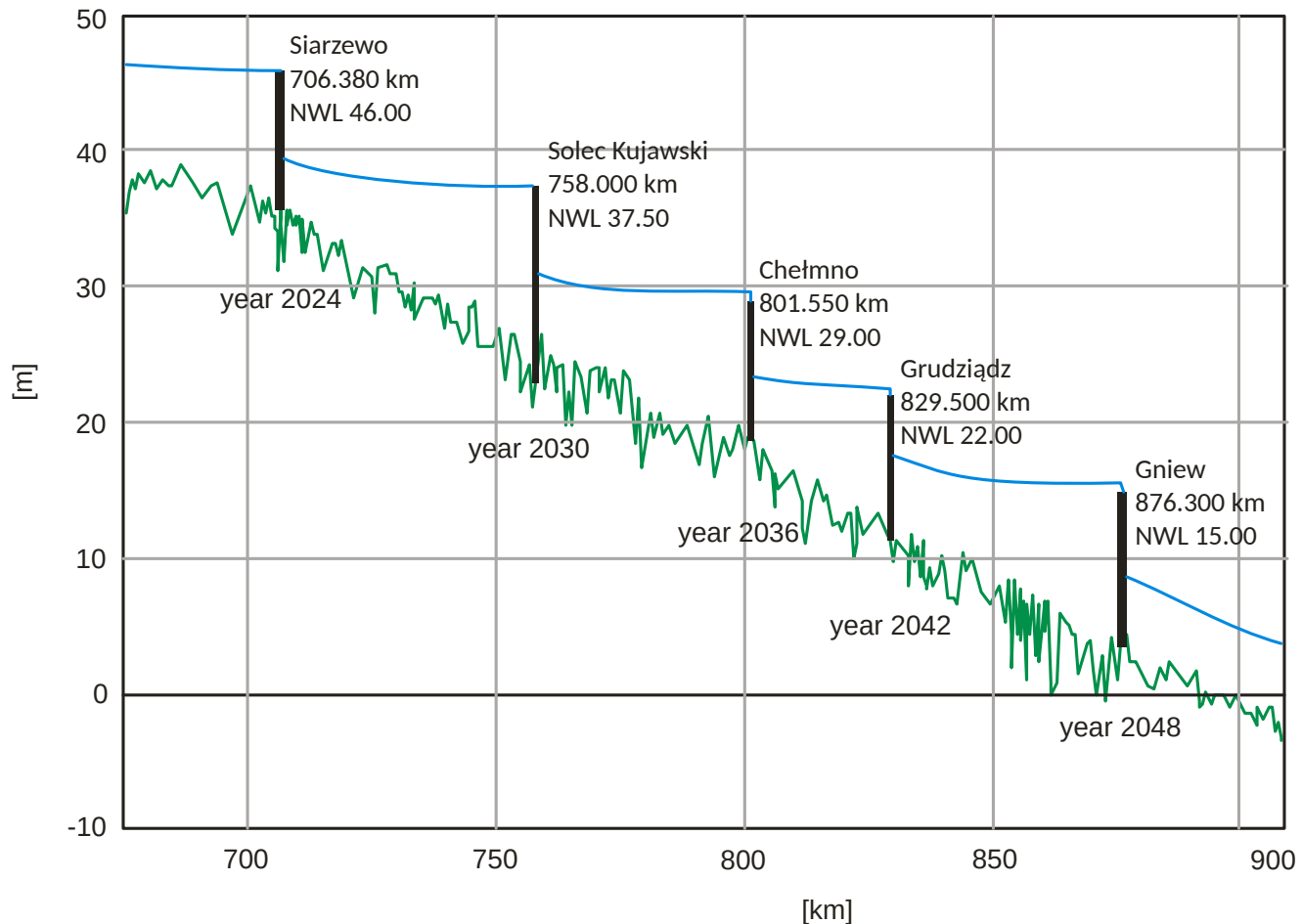

Figure 3. Planned Vistula cascade downstream the Włocławek Dam, with dams: Siarzewo, Solec Kujawski, Chełmno, Grudziąc and Gniew (commissioning year given in the Figure); NWL—normal water level, black lines—dam locations, blue line—water levels, green line-minimum bed elevations. 
Table 1. Characteristic of water dams planned in years 2024-2048 downstream Włocławek.

\begin{tabular}{cccccc}
\hline No. & Location & $\begin{array}{c}\text { River Station } \\
{[\mathbf{k m}]}\end{array}$ & Normal Water Level [m asl] & $\begin{array}{c}\text { Head Height } \\
{[\mathbf{m}]}\end{array}$ & Commissioning Year \\
\hline 1 & Siarzewo & 706.380 & 46.00 & 8.50 & 2024 \\
2 & Solec Kujawski & 758.000 & 37.50 & 8.50 & 2030 \\
3 & Chełmno & 801.550 & 29.00 & 7.00 & 2036 \\
4 & Grudziadz & 829.500 & 22.00 & 7.00 & 2042 \\
5 & Gniew & 876.300 & 15.00 & 2048 & \\
\hline
\end{tabular}

The first step is to be built in 2024 in Siarzewo. The next dams were to be completed every six years.

The aim of the article is an attempt to answer the crucial question: What will be the further changes of the Vistula riverbed, when no more dams will be built and, what will change if the dam cascade is finally constructed? The answer is given using numerical modeling of the sediment transport for different scenarios of the river infrastructure development. The long-term effect of the dam cascade on the river bed is compared to the scenario with a single currently present dam. For the Lower Vistula River, it is one of the first assessments, based on the numerical model of the river transport. The only numerical analysis for this river reach was performed by Kubrak [2], and was limited to the impact of the Włocławek dam. More recent studies have been performed by Babiński et al. [3], Babiński and Habel [4], ARUP [5], Babiński and Habel [6], but have been based on regression analyses, rather than transport modeling.

\section{Methods}

\subsection{Computation Methods}

The MIKE 11 model [8] was used for predictions of the deformation of the Vistula riverbed. This model uses the numerical solution of de Saint-Venant equations by the finite difference method to describe the one-dimensional unsteady river flow. The calculations of the bed deformation are based on the sediment transport equations performed parallel in time and space with the calculation of the unsteady river flow. The water levels at each time step in the river cross sections were calculated accounting for the changes in the crosssectional area caused by erosion or accumulation. The calculations assumed the existence of one active layer of sediment and a uniform change in erosion and sedimentation below the water table [7].

The MIKE model was used for in numerous studies on the river transport. The examples can be found in studies of Azarang et al. [9,10], Neary et al. [11], Grozav et al. [12]. The presented methodological approach is very similar to the research of Ghimire and DeVantier [13], but applied with the different numerical model.

\subsection{Boundary Conditions}

The simulations of the riverbed erosion were made using two scenarios: the absence and the construction of subsequent dams. They included the $234.400 \mathrm{~km}$ Vistula river reach, starting from the Włocławek Dam to the water gauge in Tczew ( $\mathrm{km} \mathrm{909.140).} \mathrm{The} \mathrm{Vistula}$ channel is described with 365 cross sections measured in 2016, excluding tributaries. The cross sections were generally regularly spaced. The distance was shorter at characteristic points such as bridges. Average distance was $642 \mathrm{~m}$, with a maximum of $1900 \mathrm{~m}$ and minimum of $112 \mathrm{~m}$. The simulation period was 39 years. The length of the river reach was determined on the basis of the average speed of the erosion line in the Vistula downstream the Włocławek dam. The erosion line, which at the beginning of the simulation time is located near the Solec Kujawski dam $(758.000 \mathrm{~km})$,will move by the end of the 39-year forecast period by a distance of 39 years $\times 1.9 \mathrm{~km} /$ year $=74.1 \mathrm{~km}$ and will not reach the section in Tczew $(758.000 \mathrm{~km}+74.1 \mathrm{~km}<909.140 \mathrm{~km})$. With the planned construction time scheduled of the Vistula dams, the Gniew dam $(876.300 \mathrm{~km})$ will be the closest to Tczew. The erosion line downstream this dam during the 7-year simulation period will probably 
move to a distance of $\sim 13 \mathrm{~km}$ and also will not reach the cross section in Tczew $(909.140 \mathrm{~km})$. On this basis, it was assumed that the cross section in Tczew during simulation period would not be deformed in the case of absence of dams downstream the Wloclawek, but also in the event of commissioning the planned cascade. This finding allowed to establish the lower boundary condition in the form of the flow curve in the Tczew cross section, valid for 2015 (Figure 4). The curve in this profile does not change significantly with time, so it was assumed that it would also not change in the simulation period used in the present study.

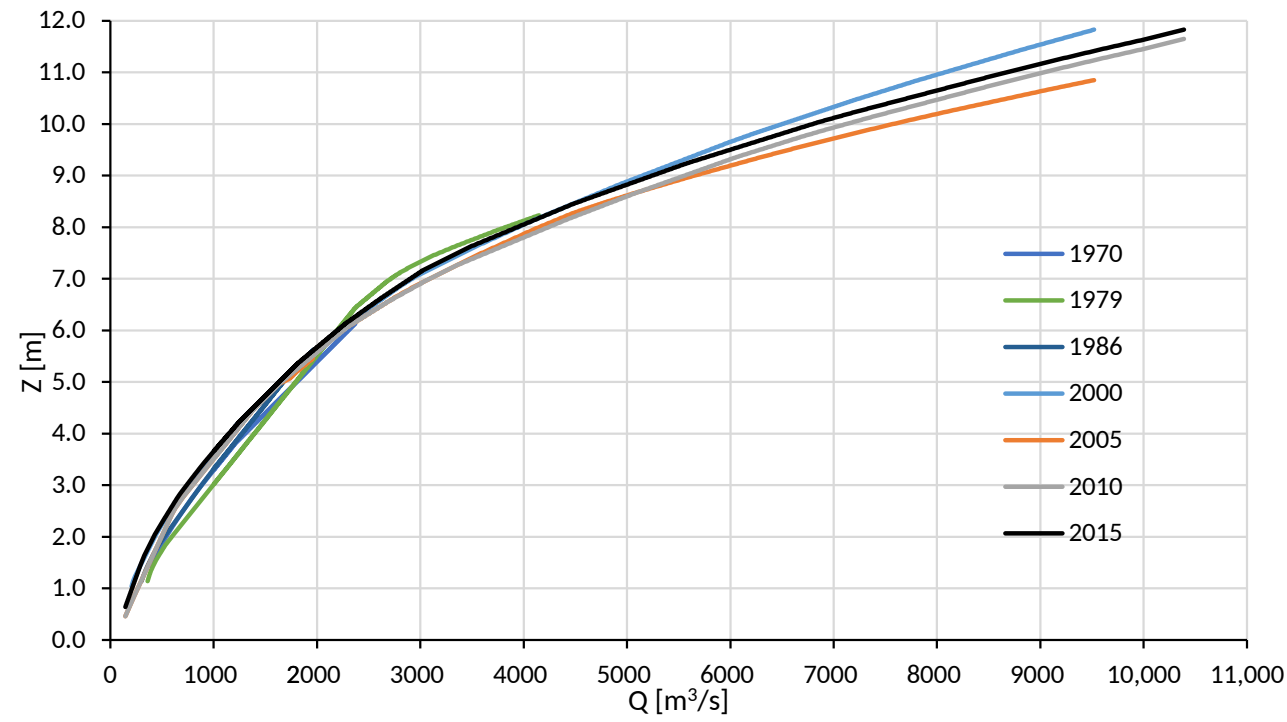

Figure 4. Rating curves for the Tczew river gauge $(909.140 \mathrm{~km})$, years 1970-2015.

The upper boundary condition for the simulations was the hypothetical flow hydrograph downstream the Włocławek Dam. It was prepared on the basis of daily observations of the flow in the Włocławek Dam cross section in the period from 2006 to 2016 with the hypothetical flood peak $Q_{0.2 \%}=9885 \mathrm{~m}^{3} / \mathrm{s}$ (from 10 June to 16 July 2007), $Q_{1 \%}=8008 \mathrm{~m}^{3} / \mathrm{s}$ (from 14 September to 6 November 2008) and $Q_{10 \%}=5195 \mathrm{~m}^{3} / \mathrm{s}$ (from 3 March to 8 April 2010) shown in Figure 5. For the 39-year simulation period, the 10-year hypothetical hydrograph was repeated four times. The simulation time starts in 2016.

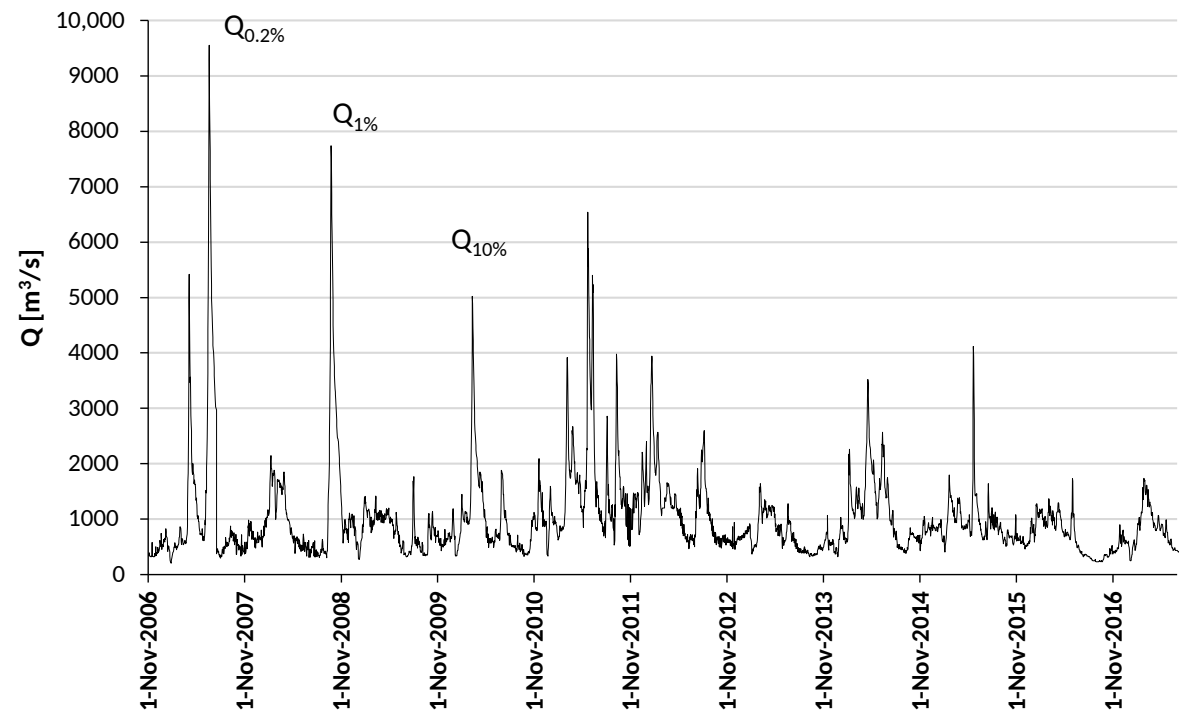

Figure 5. Flow hydrograph in Włocławek in 2006-2016. 
The simulations of the river transport required the introduction of boundary conditions for the upstream cross section, in the form of changes in its elevation or upstream sediment supply. In the performed simulations, the existence of one active layer of sediment and a uniform change in the cross-sectional bottom as a result of erosion and sedimentation below the water profile were assumed. The transport intensity in the MIKE 11 program can be calculated from various formulas. The choice of the formula defining the transport intensity, used for calculations of the bed deformation, was based on the analysis of the transport intensity computed for the conditions of the steady water flow and the available observations. On this basis, it was decided to use the Meyer-Peter and Müller formula, which does not take into account the transport of the suspended sediment.

For the analyzed river reach no systematic studies of the grain size composition of the river bed were carried out. DHV HYDROPROJEKT performed such measurements in 2015 on the river reach from $\mathrm{km} 853.00$ to $\mathrm{km} 862.00$ [14]. In 2017, DHV HYDROPROJEKT [7] repeated the study of the grain size composition of the sediment on the reach of the Vistula River from $704.25 \mathrm{~km}$ to $711.18 \mathrm{~km}$ (Figure 6).

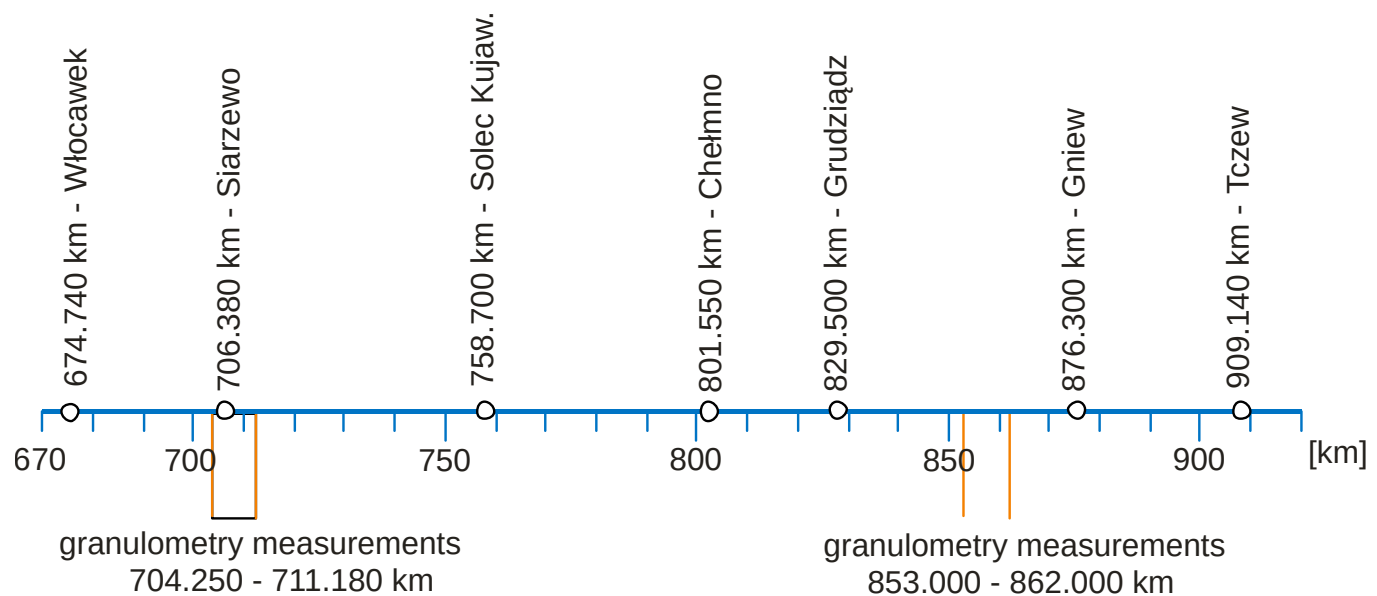

$704.250-711.180 \mathrm{~km} \quad 853.000-862.000 \mathrm{~km}$

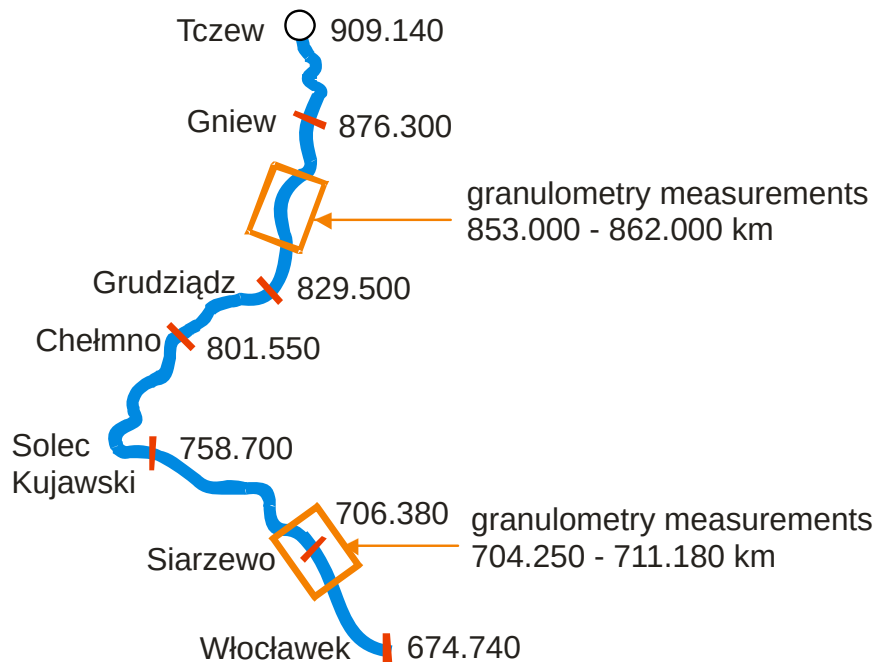

Figure 6. Granulometric measurements sites and locations of planned dams of the Lower Vistula Cascade.

Due to the lack of other measurement results, the given values of characteristic diameters were assumed as representative for the reach of the Vistula River from the dam in Włocławek to $825.00 \mathrm{~km}$ and from $825.00 \mathrm{~km}$ to the Tczew water gauge $(909.140 \mathrm{~km})$.

Taking into account the previously described state of the Vistula riverbed, the variability in values of the characteristic diameters of the bottom material shown in Figure 7 was used in the simulations. Downstream the Włocławek step—from $675.85 \mathrm{~km}$ to $694.00 \mathrm{~km}$, 
no values of the characteristic diameters of the bottom material were given due to the above-mentioned flushing of finer bottom sediments. Similarly, between $704.00 \mathrm{~km}$ and the planned Siarzewo dam-706.38 km, no characteristic bottom diameters were given, as there is no erodible material (Figure 7).

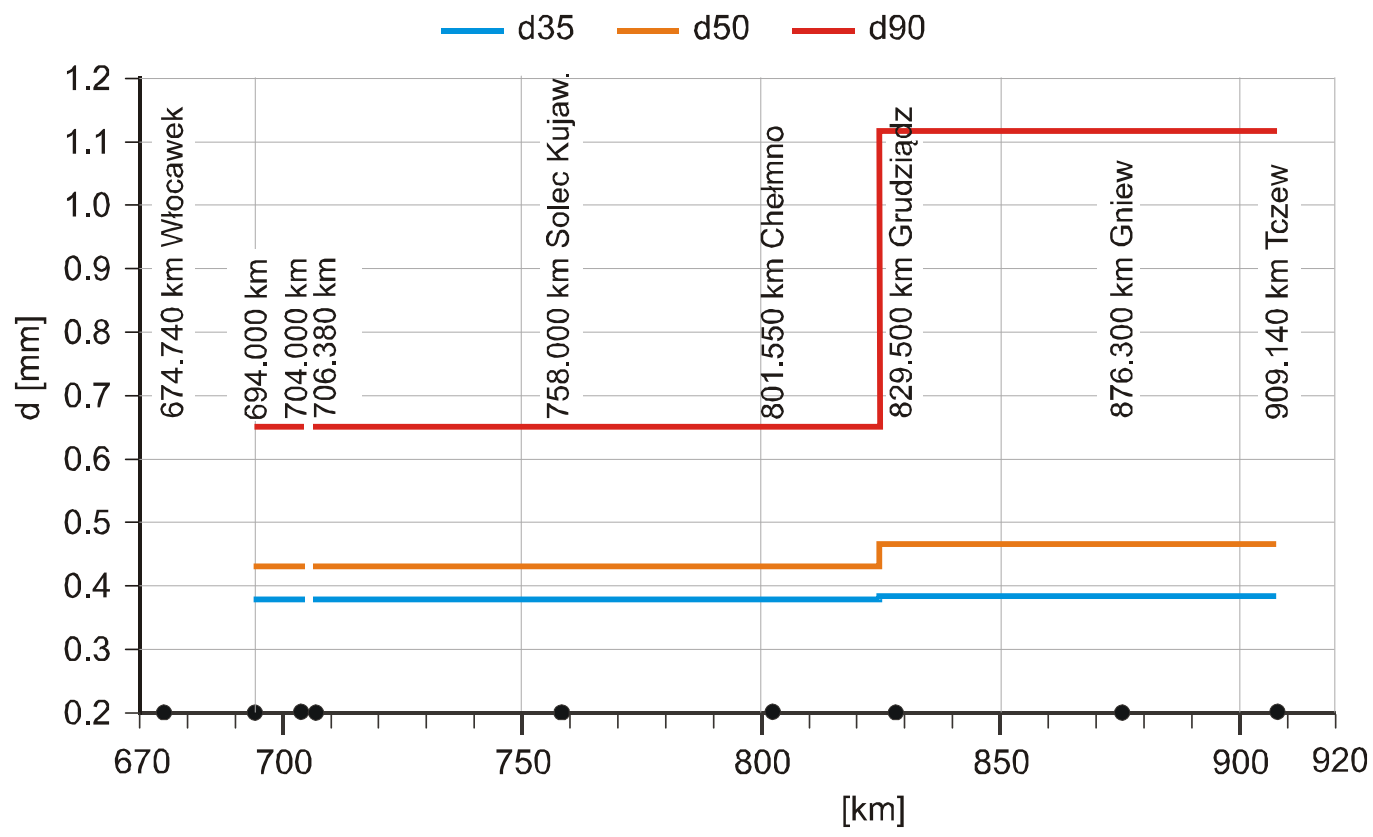

Figure 7. The changes of the characteristic grain diameters of bottom material along the Vistula River assumed for the simulations.

As aforementioned, the simulations of the sediment transport of the Vistula River downstream the Włocławek dam to the Tczew river gauge were made for a period of 39 years, starting in 2016 and ending in 2055. The changes in the cross sections and the longitudinal profile of the Vistula obtained from the calculations were used for comparisons with the simulations of the scenario where cascade of the Vistula River is being developed, according to the planned schedule (Figure 8).

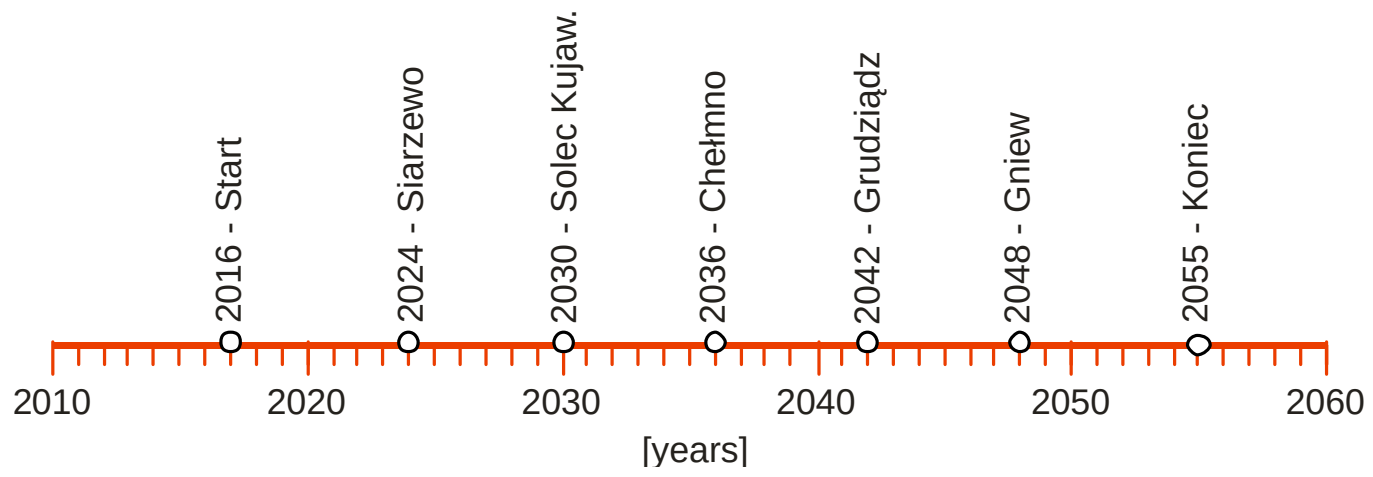

Figure 8. Time schedule of the planned cascade of the Lower Vistula River.

\section{Results}

The development of dams in the Vistula River reach causes a clear change in the hydrodynamic conditions: the water depth upstream the dams will increase, as a result of which the water velocities in the channel will decrease by $10-15 \%$ at maximum flows and by approximately $50-60 \%$ at medium and low flows. Thus, the intensity of the sediment transport will decrease, which will reduce the erosion of the river channel. However, this will not eliminate the erosion process of the bed downstream the designed dams. 
The predicted changes in the volume of the Lower Vistula channel in the period from 2016 to 2055 on the reach from Włocławek to Tczew without and with the dam cascade is shown in Figure 9. The channel volume is defined as the volume of water above the bed and is computed for bankfull water levels in 2016. The slope of the green line in relation to the time axis in Figure 9 illustrates the intensity of the increase in the volume of the bed from 2016 to 2055 when the dam cascade will not be developed. The red line in Figure 9 illustrates this change in the case the dams will be built according to the given time schedule. After the construction of the dam in Siarzewo, Solec Kujawski, the slope of the red line is clearly reduced compared to the green one, which means that erosion processes are inhibited. The construction of the dam in Chelmno will not significantly reduce the intensity of the channel volume increase. On the other hand, the construction of the dam in Grudziadz and Gniew will have an impact on the increase in the volume of the channel. The projected difference in the volume of the channel between the scenarios without and with dams is illustrated by vertical blue sections, the length of which increases significantly with the forecast time.

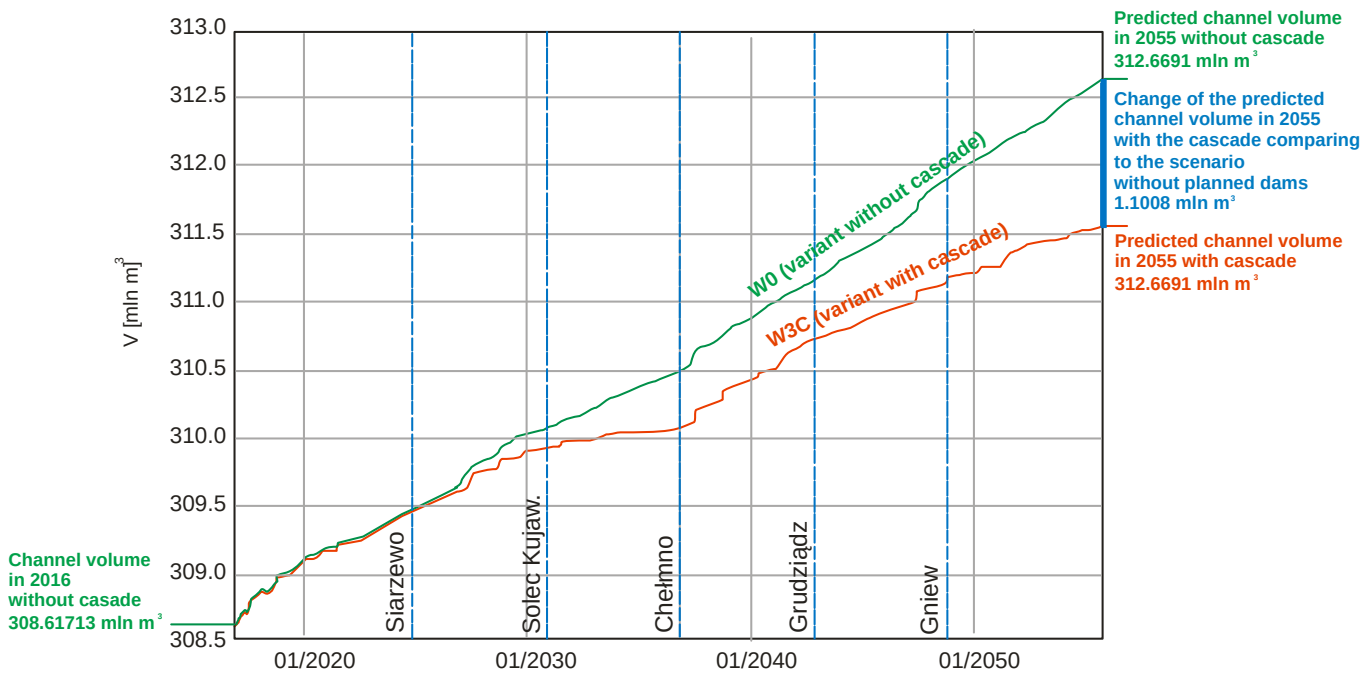

Figure 9. The effect of the planned cascade of the Lower Vistula River on the volume of the river channel.

The projected volumes of the Lower Vistula channel without and with the cascade are given in Table 2 and describe the quantitative prediction of the erosion process.

Table 2 shows that when the cascade downstream Włocławek dam will not be commissioned, there will be a further increase in the volume of the channel in the analyzed reach and in 2055 it will be 4.0518 million $\mathrm{m}^{3}$ compared to the volume in 2016. Construction of the dam in Siarzewo, similarly to Solec Kujawski, will contribute to the reduction of erosion in the prediction period compared to the scenario without the cascade, which results in a reduction in the volume of this section of the channel (positive values in the last column of Table 2). It will be influenced by sedimentation of alluvia in the reservoir part and the lack of erosion downstream the dam. On the other hand, the construction of the dam in Chełmno, Grudziądz, and Gniew will initiate erosion of the channel in the lower position of the dams, which will weaken after the construction of the subsequent dams. It is worth emphasizing that the changes in the channel volume in time caused by erosion downstream the new dams will be smaller in relation to the changes caused by the dam in Włocławek. This is evidenced by the lower slope of the red curve of the channel volume increment over time in relation to the slope of the green curve in Figure 9. This fact is also confirmed by the direction of the channel volume changes shown in Figure 10, where the changes in the channel volume were compared to the channel volume without cascade. 
Table 2. Predicted changes in the channel volume of the Vistula River, in years 2016-2055 for scenarios without and with cascade.

\begin{tabular}{|c|c|c|c|c|}
\hline River Reach & $\begin{array}{l}\text { Channel Volume in } 2016 \\
\left.\text { without Cascade [mln } \mathrm{m}^{3}\right]\end{array}$ & $\begin{array}{l}\text { Predicted Channel Volume } \\
\text { in } 2055 \text { without Cascade } \\
\left.\text { [mln } \mathrm{m}^{3}\right]\end{array}$ & $\begin{array}{c}\text { Predicted Channel Volume } \\
\text { in } 2055 \text { with Cascade } \\
{\left[\mathrm{mln} \mathrm{m}^{3}\right]}\end{array}$ & 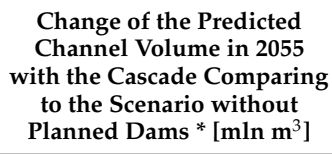 \\
\hline $\begin{array}{c}\text { Włoclawek dam }(674.74 \mathrm{~km})- \\
\text { Siarzewo }(706.38 \mathrm{~km}) \\
\end{array}$ & 76.3971 & 78.2353 & 76.7088 & 1.5265 \\
\hline $\begin{array}{c}\text { Siarzewo }(706.38 \mathrm{~km}) \text {-Solec } \\
\text { Kujawski }(758.0 \mathrm{~km})\end{array}$ & 62.6194 & 64.1469 & 62.8529 & 1.294 \\
\hline $\begin{array}{c}\text { Solec Kujawski }(758.0 \mathrm{~km}) \text { - } \\
\text { Chełmno }(801.55 \mathrm{~km})\end{array}$ & 47.9065 & 49.897 & 50.285 & -0.388 \\
\hline $\begin{array}{l}\text { Chełmno }(801.55 \mathrm{~km})- \\
\text { Grudziądz }(829.5 \mathrm{~km})\end{array}$ & 32.8651 & 32.4892 & 33.2869 & -0.7977 \\
\hline $\begin{array}{l}\text { Grudziadz }(829.5 \mathrm{~km})- \\
\text { Gniew }(876.3 \mathrm{~km})\end{array}$ & 53.8647 & 53.3471 & 53.7068 & -0.3597 \\
\hline $\begin{array}{c}\text { Gniew }(876.3 \mathrm{~km}) \text { - Tczew } \\
(909.14 \mathrm{~km})\end{array}$ & 34.9645 & 34.5536 & 34.7278 & -0.1742 \\
\hline Whole reach & 308.6173 & 312.6691 & 311.5683 & 1.1008 \\
\hline
\end{tabular}

$*(+)$ decrease of the channel volume with cascade (accumulation), (-) increase of the channel volume (erosion).

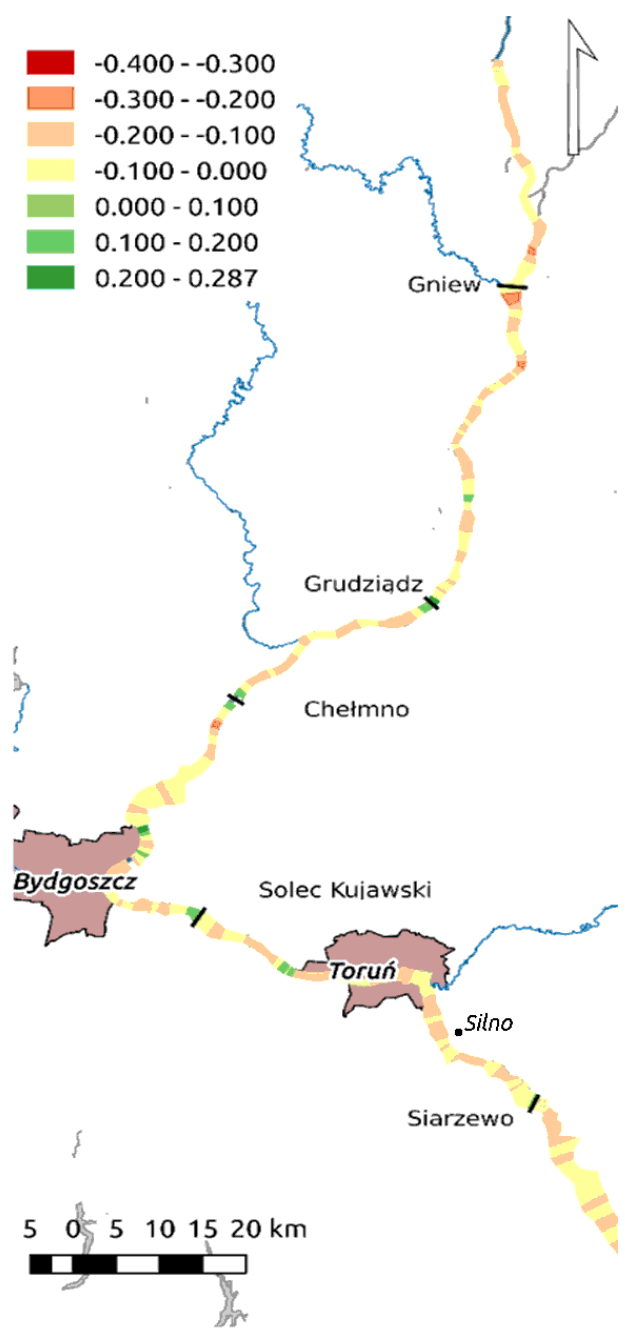

Figure 10. Predicted changes in the channel volume $\left(\mathrm{mln}^{3}\right)$ of the Lower Vistula with cascade, comparing to the scenario when cascade is not being developed. The channel volume, as the volume of water above the bed, was calculated between computation cross sections.

The erosion front downstream the Gniew Dam reached the cross section at $\mathrm{km}$ 879.009 after seven years of its operation. This means that it moved the distance of 
$879.009 \mathrm{~km}-876.300 \mathrm{~km}=2.709 \mathrm{~km}$ in 7 years, which gives the erosion front speed of $390 \mathrm{~m} /$ year. This confirms the correctness of adopting the cross section in Tczew $(909.14 \mathrm{~km})$ as the location of the lower boundary condition with the rating curve unchanged during the forecast period.

\section{Conclusions}

The development of the cascade of the Lower Vistula River will result in a clear change of hydrodynamic conditions: the depth of the flow will increase, as a result of which usually the water velocities in the channel will decrease by $10-15 \%$ at maximum flows and by approximately $50-60 \%$ at medium and low flows. Thus, the intensity of sediment transport will decrease, which will significantly reduce the bed deformation processes. The obtained results of the bed deformation calculations allow for the identification of the bed sections where erosion or accumulation of the transported sediment will occur, and what will be the evolution of these processes over time.

The scenario analysis for the cascade design requires consideration of various factors such as the size of the dam, water management policy, and limitation of downstream channel erosion. The presented analysis of the dam's impact on sediment transport should be part of the general assessment of the dam cascade suitability.

Author Contributions: Conceptualization, J.K. and E.K.; methodology, J.K. and A.K.; software, A.K.; validation, J.K., A.K., and E.K.; investigation, J.K., A.K., and E.K.; writing-original draft preparation, J.K. and E.K.; visualization, E.K. and A.K. All authors have read and agreed to the published version of the manuscript.

Funding: The work was funded by Polish National Water Management Authority (Wody Polskie https://www.wody.gov.pl/), December 2018.

Institutional Review Board Statement: Not applicable.

Informed Consent Statement: Not applicable.

Data Availability Statement: Hydrometric (river cross sections, rating curves) and galvanometric measurements used during the study were provided by a third party. Direct requests for these materials may be made to Polish National Water Management Authority (Wody Polskie https: //www.wody.gov.pl/, accessed on 27 April 2018.)

Conflicts of Interest: The authors declare no conflicts of interest.

\section{References}

1. Szydlowski, M.; Szymkiewicz, R.; Gasiorowski, D.; Hakiel, J.; Zima, P. Hydraulic potential of the Lower Vistula (Poland). In E3S Web of Conferences; EDP Science: Les Ulis, France, 2018; Volume 40, p. 3011. [CrossRef]

2. Kubrak, J. Model of the Vistula bed deformations below the Wloclawek dam [in Polish: Model procesu deformacji dna koryta Wisły poniżej stopnia wodnego we Włocławku]. Gospod. Wodna 1991, 5, 98-101.

3. Babiński, Z.; Habel, M.; Chalov, S. Prediction of the vistula channel development between Wloclawek and Torun: Evaluation with regard to the new geological survey. Quaest. Geogr. 2014, 33, 7-15. [CrossRef]

4. Babiński, Z.; Habel, M. A comparison of research approaches in estimation of volume changes of a bed load transport along a river course on the example of a large lowland river. AIP Conf. Proc. 2017, 1906, 170009. [CrossRef]

5. ARUP. Ensuring Public Safety in the Area of the Wtoctawek Dam with Water Energy and Improving the Potential of Aquatic and Dependent Water Ecosystems [in Polish: Zapewnienie Bezpieczeństwa Publicznego w Rejonie Stopnia Włocławek (...)]; Technical Report; National Water Management Authority (KZGW): Warsaw, Poland, 2012.

6. Babiński, Z.; Habel, M. Impact of a single dam on sediment transport continuity in large lowland rivers. In River SedimentationProceedings of the 13th International Symposium on River Sedimentation; CRC Press: Boca Raton, FL, USA, 2017; Volume 2016, pp. 975-982.

7. Kubrak, J.; Kiczko, A. Study on the Adaptation of the Vistula River in the Reach from Wtoctawek to the Gdansk Gulf to the Large and Small Dam Cascade —Modeling. [in Polish: Analiza Przystosowania Rzeki Wisty na Odcinku od Włocławka do Ujścia do Zatoki Gdańskiej (...)); Technical Report; DHV Hydroprojekt: Warsaw, Poland, 2018.

8. DHI. MIKE 11; Technical Report; Danish Hydraulic Institute (DHI): Hørsholm, Denmark, 2009

9. Azarang, F.; Telvari, A.; Sedghi, H.; Bajestan, M.S. Numerical Simulation of Flow and Sediment Transport of Karkheh River before the Reservoir Dam Construction Using MIKE 11 [A Case Study in Iran]. Adv. Environ. Biol. 2014, 8, 979-988. 
10. Azarang, F.; Sedghi, T.A.R.H.; Bejestan, M.S. Mathematical model for evaluating of sediment transport (Case study: Karkheh River in Iran). Indian J. Sci. Technol. 2015, 8, 1-6. [CrossRef]

11. Neary, V.S.; Wright, S.A.; Bereciartua, P. Case Study: Sediment Transport in Proposed Geomorphic Channel for Napa River. J. Hydraul. Eng. 2001, 127, 901-910. [CrossRef]

12. Grozav, A.; Beilicci, R.; Beilicci, E. Modelling of Sediment Transport of the Mehadica River, Caras Severin County, Romania. In IOP Conference Series: Materials Science and Engineering; IOP Publishing: Bristol, UK, 2017; Volume 245, p. 32030. [CrossRef]

13. Ghimire, G.R.; DeVantier, B.A. Sediment Modeling to Develop a Deposition Prediction Model at the Olmsted Locks and Dam Area. In World Environmental and Water Resources Congress 2016: Hydraulics and Waterways and Hydro-Climate/Climate Change; ASCE Publishing: Reston, VA, USA, 2016; pp. 410-420. [CrossRef]

14. DHV Hydroprojekt. Reconstruction of Regulatory Structures on the Lower Vistula River at 718-993 km. Project Documentation. Stage I-Physical Model. Model Design with the Development of the Output Data for Modeling. [in Polish: Odbudowa Budowli Regulacyjnych (...)]; Technical Report; National Water Management Authority (KZGW): Warsaw, Poland, 2015. 